\title{
Strategi Pengembangan dalam Pengelolaan Madrasah
}

\author{
Badarwan $^{1} \&$ Rustang $^{2}$ \\ ${ }^{1}$ Fakultas Tarbiyah dan Ilmu Keguruan, IAIN Kendari \\ Email: badarwan.kdi@gmail.com \\ ${ }^{2}$ Fakultas Tarbiyah dan Ilmu Keguruan, IAIN Kendari \\ Email: rustang16@gmail.com
}

\begin{abstract}
Abstrak
Penelitian ini bertujuan menganalisis strategi pengembangan dalam pengelolaan madrasah, di mana aspek-aspek yang dikaji adalah: 1) bagaimana visi pengembangan MAN Insan Cendekia Kendari; 2) bagaimana proses pengelolaan MAN Insan Cendekia Kendari. Penelitian ini merupakan penelitian kualitatif dengan metode naratif, dimana data penelitian diceritakan berdasarkan urutan peristiwa pada situasi social. Hasil penelitian menunjukkkan bahwa: Pertama, Pengembangan MAN Insan Cendekia mengarah pada terwujudnya sumberdaya manusia yang handal, secara fisik dan psikis, sehinga memiliki kesiapan dalam mengarungi kehidupan nyata di masyarakat secara luas. Kedua, proses pengelolaan MAN Insan Cendekia Kendari merupakan implementasi fungsi manajemen yang meliputi: 1) Perencanaan, yang dilakukan pada rapat kerja awal tahun terkait dengan program kegiatan. 2) Pengorganisasian, dalam bentuk struktur organisasi, dimana kepala madrasah membawahi lima wakil kepala madasah dan empat pembina asrama. 3) Pelaksanaan kegiatan, yaitu menggerakkan seluruh sumber daya sekolah untuk melaksanakan rencana-rencana madrasah. 4) Pengawasan oleh kepala madrasah, wakil kepala bidang keasramaan dan pembina asrama, guru piket dan guru asuh. 5) Evaluasi dilakukan secara bulanan dan tahunan, untuk mengetahui kesesuaian rencana dengan pelaksanaan. Implikasi studi ini adalah perlunya penelitian lebih lanjut tentang strategi menciptakan keunggulan bersaing di MAN Insan Cendekia Kendari.
\end{abstract}

\section{Kata Kunci: Strategi Pengembangan, Pengelolaan Madrasah}




\title{
Development Strategy in Madrasah Management
}

\section{Badarwan $^{1} \&$ Rustang $^{2}$}

${ }^{1}$ Faculty of Tarbiyah and Teacher Training, IAIN Kendari Email: badarwan.kdi@gmail.com

${ }^{2}$ Faculty of Tarbiyah and Teacher Training, IAIN Kendari Email: rustang16@gmail.com

\begin{abstract}
This study aims to analyze the development strategy in madrasa management, where the aspects studied are: 1) what is the vision for the development of MAN Insan Cendekia Kendari; 2) how is the process of managing MAN Insan Cendekia Kendari. This research is a qualitative research with a narrative method, where the research data is told based on the sequence of events in social situations. The results of the study show that: First, the development of MAN Insan Cendekia leads to the realization of reliable human resources, physically and psychologically, so that they have readiness to navigate real life in society at large. Second, the management process of MAN Insan Cendekia Kendari is the implementation of management functions which include: 1) Planning, which is carried out at the work meeting at the beginning of the year related to program activities. 2) Organizing, in the form of an organizational structure, where the head of the madrasah supervises five vice principals and four supervisors of the dormitory. 3) Implementation of activities, namely mobilizing all school resources to carry out madrasa plans. 4) Supervision by the head of the madrasah, deputy head of the hostel sector and hostel builder, picket teachers and foster teachers. 5) Evaluation is carried out monthly and annually, to determine the suitability of the plan with the implementation. The implication of this study is the need for further research on strategies to create competitive advantage at MAN Insan Cendekia Kendari.
\end{abstract}

\section{Keywords: Development Strategy, Madrasah Management}




\section{Pendahuluan}

Pengelolaan madrasah sudah mulai mengalami banyak perubahan melalui berbagai inovasi, baik dalam pendidikan dan pengajaran maupun pengelolaan sekolah. Dalam bidang pembelajaran, inovasi lahir sebagai adaptasi atas perkembangan teknologi informasi dan komunikasi (Nurdin, 2016). Sedangkan dalam aspek manajemen, inovasinya dapat dilihat dalam bentuk madrasah riset (Hidayati, 2019). Sejalan dengan semangat 4.0, madrasah perlu melakukan pembenahan dengan menyelenggarakan pendidikan berbasis IT, sebagai contoh pengembangan website sekolah (Laugi, 2018). Untuk madrasah yang menerapkan system boarding, penggunaan system informasi berbasis web sangat penting dalam efektifitas manajerial (Syahrul at.al, 2019).

Respon yang tinggi terhadap perubahan menjadikan beberapa madrasah menjadi magnet dan unggulan, salah satunya adalah MAN Insan Cendekia (Baiturrahman, 2019). Komitmen mutu yang tinggi ditunjukkan dalam pengelolaan madrasah ini, sehingga menjadi sekolah unggulan yang menarik berbagai kalangan untuk mempelajarinya (Upud, 2018). Perkembangan teknologi informasi dan komunikasi mendapat respon cepat dengan program literasi online (Deliasari \& Kurnianingsih, 2017). Karenanya MAN Insan cendekia dianggap melakukan pengelolaan sekolah secara efektif (Solong at.al, 2020).

MAN Insan Cendekia Kendari, yang menjadi objek studi dalam artikel ini, sedang mengikuti kesuksesan dari MAN Insan Cendekia di daerah lain di Indonesia. Kehadirannya menjadi magnet bagi masyarakat Sulawesi Tenggara dan pada saat yang sama menjadi pesaing penting bagi sekolah-sekolah sederajat. Selama empat tahun berdiri, Madrasah Aliyah Negeri (MAN) Incan Cendekia Kendari sebagai satu-satunya Madrasah Aliyah negeri di Sulawesi Tenggara yang menerapkan sistem bording school yang menggabungkan antara antara Ilmu Pengetahuan (IPTEK) dan Iman dan Takwa (IMTAK) telah menoreh banyak prestasi. Baik di tingkat lokal maupun nasional dan bahkan internasional. Beberapa prestasi yang telah diraih oleh siswa-siswi Madrasah Aliyah Negeri (MAN) Insan Cendekia Kendari yaitu juara satu syahril dan fahmil qur'an, olimpiade biologi, lomba pidato bahasa Inggris dan Arab. Pada tingkat nasional pernah mengikuti lomba robotics competition, debat bahasa Inggris dan partisipan jambore ditinkat nasional serta sederet prestasi lainnya. 
Fakta ini merupakan perwujudan dari visi MAN Insan Cendekia yang berorientasi pada perbaikan sumber daya manusia (Hartin, 2020).

Prestasi-prestasi di atas diperoleh melalui pengelolaan madrasah yang baik, melalui sistem asrama. Di dalamnya terdapat banyak program asrama seperti program pembinaan tahsin dan tahfidz, tematik dan program pembinaan kitab klasik (kuning). selanjutnya dilanjutkan dengan pembelajaran mandiri. Di sela-sela inilah siswa biasanya mengerjakan tugas sekolah dan melanjutkan tulisan mushafnya. Pada subuh hari akan dilanjutkan dengan pembelajaran bahasa. Berdasarkan fakta-fakta tersebut, artikel ini akan menganalisis lebih lanjut aspek strategi pengembangan dan pengelolaan MAN Insan Cendekia Kendari.

\section{Metode}

Penelitian ini adalah penelitian kualitatif dengan pendekatan naratif, dimana data penelitian disajikan dalam bentuk narasi terkait berbagai peristiwa pada situasi sosial (Creswell \& Poth, 2016). Aspekaspek yang diselidiki adalah visi pengembangan dan proses pengelolaan MAN Insan Cendekia Kendari. Subjek amatan yang merupakan pelaku (actor) antara lain: Kepala Madrasah, Wakil Kepala Madrasah, Guru, Tenaga Kependidikan, dan Siswa. Sedangkan aktifitas yang diselidiki terkait dengan proses perumusan visi pengembangan dan proses penerapan fungsi-fungsi manajemen. Data dikumpulkan melalui: 1) observasi (dalam pelaksanaannya, peneliti menggunakan instrument dalam bentuk pedoman pengamatan); 2) wawancara terstruktur (dalam pelaksanaannya, penulis menggunakan pedoman wawancara; dan 3) dokumentasi, membaca dokumen visi pengembangan dan proses pengelolaan madrasah. Analisis data kualitatif dilakukan secara bertahap, mulai dari pengumpulan data, reduksi data, penyajian data, hingga verifikasi atau penarikan kesimpulan (Miles \& Huberman, 1994). Pengujian keabsahan data dilakukan melalui proses triangulasi, perpanjangan pengamatan, dan peningkatan ketekunan (Anggito \& Setiawan, 2018).

\section{Hasil Penelitian atau Temuan}

\section{A. Visi Pengembangan MAN Insan Cendekia Kendari}

Visi MAN Insan Cendekia Kota Kendari adalah "terwujudnya sumber daya manusia yang berkualitas tinggi dalam keimanan dan ketakwaan, menguasai ilmu pengetahuan dan teknologi, serta mampu 
mengaktualisasikannya dalam masyarakat.”.Misinya adalah: 1) Menyiapkan calon pemimpin masa depan yang menguasai ilmu pengetahuan dan teknologi, mampunyai daya juang tinggi, kreatif, inovatif, proaktif, dan mempunyai landasan iman dan takwa yang kuat; 2) Menumbuh kembangkan minat, bakat, dan potensi peserta didik untuk meraih prestasi pada tingkat nasional sampai internasional; 3) Meningkatkan pengetahuan dan kemampuan professional pendidik dan tenaga kependidikan sesuai dengan perkembangan dunia kependidikan; 4) Menjadikan MAN Insan Cendekia sebagai lembaga pendidikan yang mempunyai tata kelola yang baik dan mandiri yang berwawasan lingkungan; 5) Menjadikan MAN Insan Cendekia sebagi model dalam pengembangan pembelajaran IPTEK dan IMTAK, serta berwawasan lingkungan bagi lembaga pendidikan lainnya; 6) Mewujudkan madrasah Adiwiyata, memanfaatkan sampah bekas menjadi lebih berguna, dan melestarikan lingkungan serta mencegah kerusakan lingkungan.

Tujuannya adalah: 1) Menghasilkan lulusan yang berkarakter Islami, berwawasan keindonesiaan, kebangsaan, internasional, dan kemanusiaan; 2) Menghasilkan lulusan-lulusan yang menguasai dasardasar ilmu pengetahuan keislaman, sains, teknologi, ilmu sosial, dan seni-budaya untuk meraih prestasi baik tingkat nasional maupun internasional; 3) Membentuk lulusan yang berkarakter dan mampu melakukan perubahan yang didasari oleh prinsip-prinsip Islam rahmatan lil'alamin. Strategi yang diterapkan adalah: 1) Menjaring calon siswa melalui seleksi Nasional peserta didik baru (SNPDB); 2) Mengembangkan proses pembelajaran yang mengacu kepada penguasaan dasar ilmu pengetahuan dan teknologi "basic knowledge of science and technology" dan kemampuan memimpin "leadership life skills" atas dasar asah, asih, asuh; 3) Menyiapkan tenaga kependidikan yang profesional dengan menerapkan "Merit System" atau penghargaan berbasis kinerja pada lembaga standar unggulan/internasional dalam bidang kesejahteraan; 4) Menciptakan suasana kehidupan yang kreatif, inovatif, apresiatif, sehat, senang, dan religius; 5) Mengadakan kerjasama dengan berbagai pihak terkait, baik di dalam maupun di luar negeri; 6) Mengadakan pelatihan secara berkala bagi para guru dan karyawan; 7) Memberikan kesempatan kepada guru dan karyawan untuk mengikuti pendidikan formal S1/S2/S3 baik di dalam maupun di luar negeri; 8) Menyediakan perpustakaan yang memadai; 9) Mengembangkan wawasan IPTEK 
dengan melakukan studi banding; 10) Mengembangkan proses pembelajaran dalam yang inovatif dan adaptif untuk antisipasi dan partisipasi dalam era otonomi dan globalisasi.

Target dibidik adalah: 1) Terciptanya kehidupan religius di lingkungan Madrasah yang memperlihatkan perilaku ikhlas, mandiri, sederhana, ukhuwah, dan kebebasan berkreasi; 2) Diperolehnya prestasi akademik yang baik bagi lulusan Madrasah Aliyah Negeri InsanCendekia; 3) Diterimanya lulusan Madrasah Aliyah Negeri Insan Cendekia Kota Kendari di Perguruan Tinggi yang berkualitas baik di dalam negeri maupun di luar negeri ( $>90 \%$ per tahun).

\section{B. Proses Pengelolaan MAN Insan Cendekia Kendari B1. Perencanaan}

Dalam setiap organisasi lembaga pendidikan tentunya terdapat manajemen didalamnya dan merupakan hal penting dalam meningkatkan kualitas lembaga pendidikan. Manajemen merupakan hal mutlak yang harus dimiliki oleh lembaga pendidikan. Salah satu fungsi manajemen ialah perencanaan. Perencanaan memberikan kerangka untuk memadukan pengambilan keputusan diseluruh organisasi. Berdasarkan penelusuran yang dilakukan oleh peneliti, perencanaan boarding school dilaksanakan untuk menghasilkan santri yang bukan hanya menguasai ilmu pengetahuan dan teknologi saja, tetapi juga memiliki wawasan keagamaan yang berprestasi bukan hanya pada tingkat nasional tetapi juga pada tingkat internasional. Dimana para santri diwajibkan tinggal di dalam asrama ketika menempuh pendidikan pada madrasah. Salah satu program unggulannya yaitu pembuatan mushaf dan juga penggunaan bahasa internasional di dalam asrama. Boarding school dilaksanakan sebagai bentuk tuntutan zaman sehingga para santri mampu bersaing bukan hanya pada ilmu pengetahuan dan teknologi saja, tetapi juga pada akhlak dan keagamaannya.

Dalam proses perencanaan boarding school dimulai pada awal tahun pembelajaran sebagaimana sekolah pada umumnya. Terlepas dari itu dalam membuat perencanaan di madrasah tidak jauh dari tujuan diadakannya boarding school yang bisa dilihat dari visi dan misi lembaga tersebut. Visi misi adalah termasuk tujuan jangka panjang dan menengah dari sebuah perencanaan. Visi misi dapat dijabarkan kedalam program-program untuk mencapainya, sehingga program program yang direncanakan termasuk ke dalam tujuan jangka 
pendek. Perencanaan yang dimaksud dengan melakukan rapat yang dilakukan oleh kepala madrasah bersama dengan jajarannya serta pembina asrama untuk menentukan hal-hal yang akan dilakukan kedepannya. Sama halnya dengan tenaga pendidik, apabila kepala madrasah merasa bahwa asrama kekurangan pembina, maka kepala madrasah akan mengajukan permohonan kepada Kementerian Agama yang kemudian calon tenaga pendidik akan diseleksi secara nasional dengan mengedepankan aspek kebutuhan yang dibutuhkan oleh madrasah. Hal ini berdasarkan pemaparan Kepala Madrasah MAN Iinsan Cendekia Kendari yang mengatakan bahwa:

"Apabila Madrasah merasa kekurangan tenaga pendidik, maka kami akan mengajukan permohonan kepada Kementerian Agama. Karena MAN Insan Cendekia merupakan madrasah dibawah naungan Kementerian Agama yang semula adalah yayasan Pak Habibie. Sehingga tenaga pendidik yang diterima di madrasah secara otomatis akan menjadi bagian dari asrama, karena asrama merupakan satu kesatuan dengan madrasah" (Dr. Abdul Basit, S.Ag.,MM., Pimpinan madrasah, 7 Agustus 2020).

Oleh sebab itu tenaga pendidik yang berada di MAN Insan Cendekia betul-betul memiliki kompetensi dalam menjalankan tugasnya. Begitu pula dengan siswa yang masuk di MAN Insan Cendekia diseleksi secara nasional yang kemudian akan langsung menjadi anggota asrama madrasah. Di dalam asrama santri kemudian akan dites sejauh mana tingkat kefasihan bacaan al-qurannya. Sebagai madrasah yang mengadopsi pembelajaran sistem internasional dimana jumlah siswa disetiap ruangan hanya berjumlah 24 siswa. Hal tersebut disampaikan oleh bapak Agustan selaku wakil kepala asrama bahhwa:

"Siswa yang masuk di MAN Insan Cendekia adalah siswa dari hasil seleksi nasional yang mana di dalam satu ruangan hanya boleh terdapat 24 siswa saja, karena harus membuat siswa dalam proses belajarnya lebih nyaman" (Agustan S.Pd.I., Wakil Kepala Asrama, 12 Agustus 2020).

Senada dengan yang disampaikan oleh bapak Agustan selaku wakil kepala asrama dibenarkan oleh kepala madrasah bahwa:

"Anak-anak yang masuk di MAN Insan Cendekia Kendari Adalah hasil seleksi nasional. Dari hasil kerja keras dari masing-masing siswa karna tidak ada bantuan sama sekali dari luar dan mereka yang diterima akan langsung masuk sebagai anggota asrama. Di kelas 
setiap angkatan hanya boleh diisi oleh 24 siswa karrna MAN Insan Cendekia kita ini taraf internasional dengan batas jumlah 24 siswa" ((Dr. Abdul Basit, S.Ag.,MM., Pimpinan madrasah, 7 Agustus 2020).

Berdasarkan pemaran di atas, jelas bahwa perencanaan dilakukan setiap awal tahun pelajaran dengan melihat berbagai aspek dengan tetap memperhatikan tujuan boarding school agar kelancaraan proses kegiatan berasrama tetap berjalan sebagaimana mestinya.

\section{B2. Pengorganisasian}

Proses pengorganisasian boarding school di MAN Insan Cendekia ditetapkan pada saat rapat. Semua warga madrasah ikut terlibat dalam kegiatan yang berkaitan dengan asrama, baik tenaga pendidik maupun kepala madrasah. Adapun pembina asrama terbagi menjadi pembina asrama putra dan pembina asrama putri. Pembina asrama tersebut merupakan hasil seleksi secara nasional yang memenuhi syarat sebagai pembina asrama yang diajukan oleh kepala madrasah. Sedangkan untuk wakil kepala asrama ditunjuk langsung oleh kepala madrasah. Pembina asrama yang tekankan adalah calon pembina yang memiliki kemampuan yang mumpuni, seperti mampu berbahasa inggris dan mampu berbahasa Arab. Kegiatan pengorganisasian tidak terlepas dari madrasah karena asrama merupakan bagian dari madrasah sehingga bentuk strukturnya dari kepala madrasah kemudian wakil kepala asrama yang selanjutnya langsung kepada pembina asrama. Sesuai dengan yang dipaparkan oleh bapak kepala madrasah bahwa:

"Dalam menentukan struktur organisasi di asrama pada dasarnya terlebih dahulu melakukan rapat bersama, wakil kepala asrama ditunjuk langsung oleh saya selaku kepala madrasah. sedangkan pembina asrama adalah mereka dari hasil seleksi nasional. Tentunya yang mendaftar adalah yang memiliki kemampuan seperti dalam persyatan. jadi yang mendaftar sebagai calon pembina asrama itu sudah memiliki kemampuan. Nah untuk struktur keorganisasian asrama itu tentunya dimulai dari saya sebagai kepala madrasah kemudian dibawah saya ada wakil kepala asrama setelah itu barulah langsung kepada pembina asrama. Jadi di asrama itu ada empat pembina asrama dua untuk pembina asrama putra kemudian juga dua untuk pembina asrama putri. Di dalam asrama itu sendiri memiiki beberapa seksi untuk mengkoordinir kegiatan yang berkaitan dengan asrama. Untuk seksi-seksi dalam organiasi asrama diisi oleh 
santri/santriwati yang ada di dalam asrama" (Dr. Abdul Basit, S.Ag.,MM., Pimpinan madrasah, 7 Agustus 2020).

Hal tersebut sesuai dengan wawancara dengan bapak Agustan yang mengatakan bahwa:

"Jadi dalam menentukan wakil kepala asrama itu adalah kepala madrasah, sedangkan untuk pembina asrama itu dari pusat dengan cara apa, yaitu dengan cara melakukan penyeleksian secara nasional. jadi pembina asrama itu memang harus betul-betul berkompeten, dan yang mengusulkan pembina asrama itu adalah kepala madrasah sehingga tidak serta merta dituunjuk begitu saja, harus ada kempuan. berbicara mengenai strukturnya yah tentu saja pertama kan kepala madrasah kemudian turun kesaya sebagai wakil kepala asrama nah setelah itu barulah pembina asrama. Baik itu pembina asrama putra maupun putri. Di dalam asrama itu juga ada seksi-seksi atau koorditor dan mereka itu adalah santri maupun santriwati. Di asrama juga itu ada yang namanya pengasuh dan pengawas" (Agustan, Wakil Kepala Arama, 12 Agustus 2020).

Senada dengan itu, melalui wawancara bersama dengan salah satu guru juga mengatakan demikian. Beliau mengatakan bahwa:

"Struktur asrama di MAN IC itu juga ada sendiri ya dari kepala sekolah turun kepada wakil kepala asrama kemudian kepada pembina asrama. Adapun pembantu-pembantumya itu adalah santri santriwati yang yang punya tugas sendiri yang dipilih melalui pemiliihan" (Ruhaniyah, S.Ag., 24 Agustus 2020).

Jadi dapat disimpulkan bahwa dalam membentuk struktur organisasi di asrama MAN Insan Cendekia tetap berada dalam tanggung jawab kepala madrasah mekipun itu pembina asrama berasal dari hasil seleksi nasional dimana strukturnya dimulai dari pemegang tanggung jawab tertinggi adalah kepala madrasah, wakil kepala asrama yang kemudian barulah pembina asrama.

Berdasarkan struktur organisasi setiap guru mempunyai tanggung jawab masing-masing: 1) Kepala asrama sebagai pemegang kekuasaan tertinggi bertugas mengawasi dan memberikan masukan apabia ada hal-hal yang perlu untk dilakukan. Melakukan rapat setiap sebulan sekali dan rutin bersama melihat hal-hal yang perlu ditambah ataupun dikurang di asrama; 2) Wakil Kepala asrama bertugas untuk mengawasi seluruh asrama baik pada asrama putra maupun asrama putri dan membuat laporan kepada kepala asrama terkait dengan perkembangan maupun kegiatan-kegiatan di asrama; 3) Pembina 
asrama yang terbagi menjadi dua yaitu pembina asrama putra dan pembina asrma putri masing-masing bertugas mengontrol dan memegang kuasa atas asrama. Asrama putra dipegang oleh pembina asrama putra dan asrama putri dipegang oleh pembina asrma putri.

\section{B3. Pelaksanaan}

Penerapan fungsi selanjutnya adalah fungsi pelaksanaan yang dimana dilaksanakan pada saat ada hal yang harus diperbaiki. Apabila hal tersebut cukup ringan maka pimpinan melakukan peneguran secara personal namun apabila masalah tersebut sudah menjadi besar maka akan dibahas pada forum rapat. Dalam menjalankan fungsi pelaksanaan di asrama tidak serta merta langsung di bawa kepada wakil kepala asrama tetapi tetap akan diambil alih oleh pembina asrama terlebih dahulu. Di dalam asrama santri memiliki pengasuh dan juga pengawas, pengasuh melaksanakan tugasnya seminggu sekali namun santri bisa berkonsultasi kapan saja. Pengasuh atau guru asuh adalah selayaknya orag tua pengganti di dalam asrama. Pada pertemuan rutin, santri dan guru asuh akan melakukan sharing permasalahhan terkait dengan masalah yang dihadapi santri dalam berasrama, baik masalah pembelajaran maupun kehidupan sosial. Santri juga akan diajak berpikir dewasa dalam menyelesaikan masalah yang terkait kehidupan pribadi maupun kehidupan sosial. Biasanya pengasuh memegang 10-15 santri yang kemudian mendengarkan keluhan-keluhan santri lalu memberikan masukan-masukan. Sedangkan Pengawas adalah guru-guru piket malam yang telah terstruktur dalam mengarahkan santri saat belajar yang disebut dengan study in coridor.

Seperti yang dipaparkan oleh ibu Ruhaniyah, S.Ag., beliau mengatakan bahwa:

"Selain pembina asrama yang bertugas dalam pelaksanaan berasrama, ada juga pengasuh atau guru asuh dan pengawas. salah satu guru asuh adalah saya yang memegang 10 santriwati, jadi setiap guru itu puya anak asuh. Tugas guru asuh itu apa, gunanya adalah sebagai pengganti orang tua. Ketika mereka ada masalah maka mereka boleh kapan saja datang ke kami. Mau curhat tentang kehidupan di asrama, boleh. Mau curhat ini dan itu boleh. Kami juga memberikan arahan,masuan terkaitt dengan pelajaran dan sebagainya. Beda lagi dengan pengawas, mereka adalah semua guru yang mngontrol siswa saja saat belajar dan sudah ada piket masing-masing" (Ruhaniyah, S.Ag., 22 Agustus 2020). 
Senada dengan itu juga dsampaikan oleh bapak Binar yang mengatakan bahwa:

"Di asrama itu selain pembina asrama sebagai pelaksana yang katakanlah 24 jam selalu bertemu dengan santri ada juga yang bertugas sebagai guru asuh. Guru asuh ini memegang 10-15 santri, mereka inilah sebagai pengganti orang tua santri. Mereka yang akan bertemu seminggu sekali, biasanya hari kamis sore lepas pembelajaran sekolah ya atau kalau tidak hari sabtu. Ada sharing di situ, atau kalau ada yang kehilangan karna tercecer atau karna ada tangan jail ya akan dibahas di situ. Beda lagi dengan pengawas atau guru piket malam, mereka tugasnya mengontrol santri supaya mereka belajar di luar kamar" (Binar, S.Pd., Guru asuh, 23 Agustus 2020”

Dalam proses kegiatan asrama akan dilaksanakan pada subuh hari sampai pukul 06.30 WITA. Selanjutnya pelaksanaan kegiatan madrasah sebagaimana biasanya hingga pukul tiga sore. Kemudian kegiatan kesiswaan hingga pukul lima sore. Pelaksanaan kegiatan asrama berlanjut setelah maghrib dan kegiatan tersebut terstruktur. Seperti yang dikatakan santri bahwa:

"Pelaksanaan kegiatan asrama itu dimulai sebelum subuh, kan harus sholat tahajud dulu, setelah itu sholat subuh kemudian tadarus dan lain sebagainya. Kegiatannya itu sudah terstruktur, nanti kegiatannya beranjut lagi setelah sholat maghrib yang didampingi oleh pembina asrama" (Ammar Luaiyyan Addany, santri MAN IC, 25 Agustus 2020).

Senada dengan yang disampaikan oleh santri tersebut, pembina asrama pun mengatakan hal yang demikian. Berikut peryataan yang disampaikan oleh bapak Ramadan Koso, S.H.I., yang mengatakann bahwa:

"Pelaksanaan kegiatan asrama itu berlanjut dan telah tersruktur, selaku pelaksana pembina asrama yang akan mengarahkan santri. Namun sebenarnya mereka sudah paham kegiatan apa yang akan dilaksanakan karna kan ada jadwal, kita sebagai pembina asrama tinggal mengarahkana saja. Kegiatan asrma itu dimulai dari maghrib sampai pagi” (Ramadan Koso, S.H.I., Pembina asrama MAN IC, 25 Agustus 2020).

Sehingga dapat disimpulkan bahwa Pelaksanaan kegiatan asrama melalui mekanisme yang telah ada, wakil kepala asrama akan melakukan rapat bersama pembina asrama apabila memungkinkan, Pelaksanaan kegiatan asrama juga terstrukur yang dibina langsung 
oleh pembina asrama. Ditengah pandemi saat ini, proses kegiatan asrama tetap berlangsung yang dimana pembina asrama tetap mengarahkan santri untuk mengerjakan tugas-tugas asrama yang diberikan. Begitu pula dengan kepala madrasah dan wakil kepala madrasah tetap mengarahkan santri untuk belajar dengan giat. Adapun bentuk jadwal kegiatan asrama sebagai berikut:

Tabel 1 Jadwal kegiatan santri di asrama MAN IC

\begin{tabular}{|l|l|}
\hline \multicolumn{1}{|c|}{ Waktu } & \multicolumn{1}{|c|}{ Jenis Kegiatan } \\
\hline $04.00-05.55$ & $\begin{array}{l}\text { Bangun tidur, bersih diri, tahajjud, tadarrus } \\
\text { alquran, sholat subuh, wirid, doa, } \\
\text { pembinaan keagamaan dan kebersihan } \\
\text { asrama. }\end{array}$ \\
\hline $05.55-06.20$ & $\begin{array}{l}\text { Makan pagi dan persiapan ke gedung } \\
\text { pendidikan }\end{array}$ \\
\hline $06.20-07.00$ & $\begin{array}{l}\text { Apel pagi, pemberian mufradat, sholat } \\
\text { dhuha, tahfizh dan tilawah }\end{array}$ \\
\hline $07.00-15.30$ & Jam PBM di gedung pendidikan \\
\hline $15.30-16.00$ & Sholat ashar berjamaah \\
\hline $16.00-17.15$ & Peningkatan mutu akademik \\
\hline $17.15-17.45$ & Persiapaan ke masjid \\
\hline $17.45-18.40$ & $\begin{array}{l}\text { Tadarus al-quran , sholat maghrib, wirid } \\
\text { dan doa. santap malam }\end{array}$ \\
\hline $18.40-19.30$ & Kegiatan Pembinaan keagamaan \\
\hline $19.30-20.00$ & Sholat isya berjamaaah \\
\hline $20.00-22.00$ & $\begin{array}{l}\text { Belajar mandiri, tutorial dan pembinaan } \\
\text { keagamaan }\end{array}$ \\
\hline $22.00-04.00$ & Istirahat malam \\
\hline Dengan
\end{tabular}

Dengan melihat jadwal kegitan tersebut, santri akan terbiasa membagi waktunya dengan tertib. Kedisiplinan yang tertata ini mammpu membawa prestasi bagi santri dan asrama maupun madrasah.

\section{B4. Pengawasan}

Penerapaan fungsi selanjutnya adalah fungsi pengawasan Dalam sistem pengawasan di asrama semua guru terlibat dalam pengawasan. Begitupula dengan kepala madrasah, wakil kepala madasah secara tidak langsung mengawasi walaupun tidak secara 
terus menerus dan pembina asrama bertugas mengawasi kegiatan di dalam asrama setiap waktu. Wakil kepala asrama dalam menjalankan tugas akan meminta pembina asrama untuk melaporkan keadaan di dalam asrama atau terjun langung meliht keadaan di dalam asrama, baik itu asrama putra maupn asrama putri. Seperti yang dipaparkan oleh wakil kepala asrama yang mengatakan bahwa:

"Dalam proses pengawasan di asrama itu juga ada kepala madrasah yang kadang turun melihat keadaan asrama atau kalau tidak beliau meminta kepada saya. Adapun saya juga akan datang langsung ke asrama untuk mengawasi bagaimana kegiatan asrama. Kadang juga saya meminta kepada pembinna asrama untuk melaporkan keadaan di dalam asrama. Pada saat malam hari ada pengawas guru atau guru piket yang datang langsug mengontrol santri dalam proses belajar malamnya. Ada juga guru asuh yang bertugas seminggu sekali betemu dan mengawasi santri" (Agustan, Wakil Kepala Arama, 12 Agustus 2020).

Senada dengan itu juuga disampaikan oleh bapak Amir Hamzah, S.Pd.,M.E., beliau mengatakan bahwa:

Secara keseluruhan semua guru terlibat mengawasi kegiatan yang berkaitan dengan asrama, namun yang lebih bnyak berinteraksi dengan santri dalam asrama adalah pembina asrama itu sendiri. Karna pembina asrama itu tinggal di dalam asrama sehingga lebih banyak terlibat dalam pengawasan" (Amir Hamzah, S.Pd., M.E., staf tata usaha MAN IC, 19 Agustus 2020).

Begitu pula dengan yang disampaikan oleh salah satu santriwati yang mengatakan bahwa:

Di dalam asrama itu pembina asrama yang paling banyak berinteraksi dan melakukkan pengawasan. ada juga guru piket yang tugasnya mengawasi pada malam hari, biasanya mereka berganti-gantian. kalau kepala sekolah dengan wakil kepala asrama hanya kadangkadang datang, tidak setiap waktu" (Naila, santriwati, 25 Agustus 2020).

Dari pemaparan tersebut dapat disimpulkan bahwaa dalam menjalankan fungsi pengawasan asrama, Kepala madrasah dan wakill kepala asrama tetap melakukan pengawasan kepada santri dengan datang langsung ke asrama atau dengan melihat laporan dari pembina asrama, Pembina asrama melakukan pengawasan setiap waktu di dalam asrama. Begitupula dengan guru piket akan datang setiap malam untuk mengontrol kegiatan para santri. 


\section{B5. Evaluasi}

Penerapan fungsi selanjutnya yaitu fungsi evaluating atau evaluasi. Evaluasi yang dimaksud yaitu suatu kegiatan untuk memperoleh kepastian serta target apakah dalam pelaksanaan kegiatan di dalam asrama sudah dilakukan sesuai dengan perencanaan yang telah dibuat atau malah menyimpang dari perencanaan yang telah disusun sejak awal. Dalam melakukan evaluasi di asrama MAN IC Kendari melakukan rapat bulanan, penilaian dan juga rapat tahunan untuk mengevaluasi sejuh mana perencanaan terlaksana. Di dalam asrama juga mempunyai raport sendiri. Jadi di MAN IC terdapa dua raport yang diimliki oleh santri yaitu raport asrama dan jugga raport madrasah. Ujian dilaksanakan sama seperti pada ujian biasanya pada akhir semester. Apa-apa yang diajarkan di dalam asrama itulah yang akan di ujiankan.

Sesuai dengan yang disampaikan oleh pembina asrama ibu Khaerunnisa, S.Pd.I., beliau mengatakan bahwa:

"Dalam mengevaluasi santri, kan setiap semester ada yang namanya ujian asrama, jadi semua pelajaran asrama dievaluasi. Mulai dari kitab yang dikaji setiap pekan (tafsir, ta'imul muta'allim, safinatunnnajah, dan lai-lain). Ujian mufradat, vocab, hadits arbain. Kemudin ujian praktek seperti qiraatul quran, kaifyiat shalat, kaifiyat wudhu, muhadtsah dan muhadharah" (Khaerunnisa, S.Pd.I., Pembina asrama putri, 27 Agustus 2020).

Senada dengan itu juga disampaikan oleh wakil kepala asrama, beliau mengatakan bawa:

"Dalam mengevaluasi santri itu ada ujian asrama, jadi di asrama itu punya raport sendiri sehingga santri pada saat lulus di MAN IC ini punya raport asrama dan juga punya raport madrasah, jadi ada dua raport. nah evaluasinya itu dengan mengujiankan apa yang dpelajari di dalam asrama" (Agustan, S.Pd.I., Wakil kepala asrama, 12 Agustus 2020).

Sehingga dapat disimpulkan bahwa dalam melakukan evaluasi di asrama dengan melakukan rapat bulanan yang dilakukan oleh kepala bidang keasramaan bersama pembina asrama ntuk mengetahui sejauh mana kegiatan keasramaan berlangsung. Di asrama juuga melakukan ujian akhir semester sama dengan ujian sekolah pada umumnya, yang membedakan adalah apa yang diujiankan di dalam asrama. nilai yang ada dalam raport akan menjadi acuan apakah perencanaan yang dilakukan pada awal tahun berjalan dengan baik 
ataukah tidak. Dalam mengevaluasi juga wakil kepala asrama melakukan rapat setiap bulan sekali untuk melihat apa yang harus ditambah dan apa yang harus dikurang.

\section{Pembahasan}

\section{A. Visi Pengembangan}

Wacana dasar terbentuknya organisasi (apapun bentuknya) selalu mensyaratkan pencapaian tujuan bersama, yang tidak dapat dicapai jika dikerjakan secara individual (Robbins \& Judge, 2012). Tujuan-tujuan bersama tersebut biasanya dirumuskan oleh para pendiri (founding fathers) untuk memandu gerak langkah organisasi. Oleh para penerus, seiring dengan perkembangan keorganisasian, dilakukan perumusan ataupun modifikasi tetapi tetap sejalan dengan semangat dasarnya. Salah satu bentuknya adalah perumusan visi organisasi yang berdimensi jangka panjang. Karenanya, visi sekolah/madrasah haruslah mencerminkan suatu target besar di masa mendatang. Dalam konteks kekinian, rumusan visi, misi, tujuan, dan program sekolah secara sistematis terdokumentasi dalam bentuk rencana strategis (RENSTRA). Cara-cara demikian menunjukkan tingkat kesiapan sekolah yang sangat tinggi terhadap perubahan lingkungan (Syahrul, 2016), juga membantu menetralisir kondisi organisasi di masa ketidakpastian (Syahrul, 2015). Meskipun demikian, kondisi lain yang penting diperhatikan adalah munculnya pesaing tak kasat mata (Syahrul, 2019), terutama ketika era disrupsi melanda berbagai organisasi dunia (Kasali, 2019). Karenanya, dalam konteks visi pengembangan sekolah, kesiapan kepemimpinan di masa krisis sangatlah penting (Sastramayani \& Badarwan, 2019).

Proses mewujudkan visi organisasi menjadi tugas penting para pemimpin, dimana mereka secara terus menerus mengingat seluruh warga organisasi tentang visi tersebut. Dalam konteks ini, wacana kepemimpinan selalu actual, terutama ketika organisasi dihadapkan pada situasi keorganisasian yang mengungkung. Para pemimpin harus tampil sebagai pembeda, merumuskan berbagai strategi pemecahan masalah (Nanus \& Dobbs, 1999). Jika seorang manajer bekerja dibatasi oleh struktur organisasi, maka pemimpin melampaui batasbatas structural tersebut. Inovasi merupakan salah satu karakteristik kepemimpinan (Syahrul, 2015). Dengan demikian, visi pengembangan sekolah/madrasah bertumpu pada kehadiran seorang pemimpin, seorang yang mampu membuat perbedaan. 


\section{B. Perencanaan}

Perencanaan boarding school dilaksanakan untuk menghasilkan santri yang bukan hanya menguasai ilmu pengetahuan dan teknologi saja, tetapi juga memiliki wawasan keagamaan yang berprestasi bukan hanya pada tingkat nasional tetapi juga pada tingkat internasional. Dimana para santri diwajibkan tinggal di dalam asrama ketika menempuh pendidikan pada madrasah. Salah satu program unggulannya yaitu pembuatan mushaf dan juga penggunaan bahasa internasional di dalam asrama. Boarding school dilaksanakan sebagai bentuk tuntutan zaman sehingga para santri mampu bersaing bukan hanya pada ilmu pengetahuan dan teknologi saja, tetapi juga pada akhlak dan keagamaannya. Dalam proses perencanaan boarding school dimulai pada awal tahun pembelajaran sebagaimana sekolah pada umumnya. Terlepas dari itu dalam membuat perencanaan di madrasah tidak jauh dari tujuan diadakannya boarding school yang bisa dilihat dari visi dan misi lembaga tersebut. Hal ini sesuai dengan pemaparan Muchammad Muslim yang mengatakan bahwa perencanaan adalah suatu kegiatan atau aktivitas dalam rangka menetapkan tujuan yang ingin dicapai, apa yang harus dilakukan, dan siiapa pelaksana langkah-langkah untuk mencapai tujuan tersebut, serta bagaimana cara langkah tersebut dalam dilaksanakan denggan maksimal, efektif dan efisien. Perencanaan dapat dilaksanakan dengan penentuan tujuan yang ingi dicapai dengan visi, misi, tujua yang iingin dcapai. Penentuan SDM selaku pelaksana langkah-langkah mencapai tjuan dan perencannaan program (Muslim, 2018).

Hal tersebut sesuai dengan perencanaan menurut Handoko meliputi pemilihan atau penetapaan tujuan-tujuan organisasi. penentuan strategi, kebijaakan, proyek, program, prosedur, metode, sistem, anggaran, dan standar yang dibutuhkan untuk mencapai tujuan (Husaini, 2013). Sesuai dengan pemaran Astuti dalam penelitian (Akilah, 2017), Perencanaan sumber daya manusia merupakan kegiatan menaksir menghitung/menghitung kebutuhan sumber daya manusia dan selanjutnya merumuskan upaya-upaya yangg perlu dilakukan untuk memenuhi upaya-upaya tersebut. Upaya tersebut mencakup kegiatan menyusun dan melaksanakan rencana jumlah dan kualifikasi personel ang diperlukan tersedia pada saat dan posisi yang tepat sesuai dengan tuntutannya. Hal tersebut menjellaskan bahwa proses perencanaan dilaksanakan diawal tahun guna mencapai tujuan yang diharapan. 


\section{Pengorganisasian}

Proses pengorganisasian boarding school di MAN Insan Cendekia ditetapkan pada saat rapat. Semua warga madrasah ikut terlibat dalam kegiatan yang berkaitan dengan asrama, baik tenaga pendidik maupun kepala madrasah. Adapun pembina asrama terbagi menjadi pembina asrama putra dan pembina asrama putri. Pembina asrama tersebut merupakan hasil seleksi secara nasional yang memenuhi syarat sebagai pembina asrama yang diajukan oleh kepala madrasah. sebagaimana dalam (Muslim A. , 2017) pengorganisasian melibatkan penentuan berbagai kegiatann seperti pembagian pekerjaan kedalam berbagai tugas khusus yang harus dilakuakan guru dan peserta didik dalam proses pembelajaran, seperti menentukan pengajar, menentukan materi yang dapat menunjang tercapainya tujuan dari penyelenggaraan boardiing school dan menentukan waktu atau jadwal pelaksanan kegiatan. Dengan adanya pengorganisasian dapat memberikan gambaran bahwa kegiatan belajaar dan mengajar mempunyai arah dan penangung jawab yang jelas. Kepala sekolah dalam memeberkan fasilitas dan kelengkapan pembelajaran. sedangkan keduduukan guru untuk menentukan dan mendesain pembelajaran dengan mengorganisasikan alokasi waktu, desain kurikulum, media dan kelengkapan pembelajran dan lainnya.

Manullang berpendapat bahwa pengorganissasian aadalah pengelompokan aktifitas yang akan dilakukkan atau pendistribusian tugas dan fungsi kepada setiap individu yanng ada dalam organisasi (Torang, 2014). Oleh karena itu pembagaian kerrja harus disusun dalam suatu struktur yang kompak dengan huungan kerja yang jelas agarr antara satu denggan yang lainnya mampu melengkapi daalam ranngka mencapai tuujuan. Strukturr organisasi terrseebut diistilahkan dengan "segi formal" dalam komponen pengorganisasiian, kkarena merupakn kerngka yang terrdiri dari satuan-satuan kerja atu fungsifunggsi yang memiiliki wewenang dn anggung jawab yang bersifat hierarki/bertingkat (Yacoeb, 2013)

\section{Pelaksanaan}

Selanjutnya proses pelaksanaan boarding school dilakukan lebih banyak oleh pembina asrama dengan mengikuti ketentuan atau arahan dari kepala madrasah yang sesuai dengan perencanaan awal. Hal tersebut sesuai dengan pendapat Siagian dalam buku (Daryanto, 2013) yang mengatakan bahwa pengarahan dapat didefinisikan sebagai keseluruhan usaha untuk mendorong para anggota organisasi 
agar mau dan ikhlas bekerja dengan sebaik mungkin demi tercapainya tujuan dengan efektif, efisien dan ekonomis. Begitu juga yang disampaikan oleh Sudjana dalam penelitian (Tawakal, 2016) pelaksanaan dapat diartikan ebagai upaya pimpinan untuk menggerakkan seseorang atau sekelompok orng yang diipimpin dengan menumbuhkan doroongan atau motif dalam diri orang-orang yang dipimpin untuk melakukan tugas atau kegiatan yang diiberikan kepadanya sesuai dengan rencana dalam rangka mencapai tujuan orgganisasi.

\section{E. Pengawasaan}

Proses pengawasan asrama di MAN Insan Cendekia melibatkan semua guru yang ada di madrasah. Guru memiliki jadwal piket untuk mengawasi santri, begitu pula pembina asrama mengontrol kegiatan yang ada dalam asrama. Hal tersebut sesuai dengan yang disampaikan Terry yang menetapkan empat langkah yang harus dilakuan dalam proses pengawasan yaitu: Pertama, menetapkan standar atau dasar pengawasan. Kedua, mengukur kinerja. Ketiga, bandingkan kinerja dengan standar kinerja dan tetapkan perbandingan/perbedaannya. Keempat, koreksi penyimpangan sebagai langkah perbaikan (Torang, 2014).

Begitupula dengan yang disampaikan oleh (Zaenal, 2018) bahwa proses pengawasan program boarding school selain dilakukan oleh pengurus yayasan terhadap manajemen di asrama maupun dii sekolah, pengawasan juga dilakukan oleh pengawas sekolah terhadap manajemen di sekolah, serta pengawasan dan pemantauan yan dilakukan oleh kepala sekolah terhadap pelaksanaan kegiatn di sekolah. Pengawwasan boarding school biasanya dilakkan ooleh pendamping asrama secara langsung tetapi kepala madrasah juga ikut mengawasi secara tidak langsung walaupun tiidak terus menerus. Tapi untuk kegiatan kajian kitab pelaksanaannya diawasi langsung oleh kepala madrasah (Mubarok, 2018). Oleh karena itu kegiatan pengawasan juga akan menentukan keberhasilan dalam suatu organisasi.

\section{F. Evaluasi}

Dalam melakukan evaluasi di MAN Insan Cendekia, melakukan rapat evaluasi bulanan, penilaian dan juga rapat evaluasi tahunan. asrama memiliki raport sendiri untuk para santri. Jadi santri mempunyai dua raport ketika telah selesai di madrasah tersebut. santri akan dievaluasi persemester untuk mengukur sejauh mana 
perencanaan berjalan dengan lancar. Hal tersebut sesuai dengan yang disampaikan (Siregar, 2011) Evaluasi merupakan salah satu komponen dari sistem yang harus dilakukan secara sistematis dan terencana sebagai alat untuk mengukur keberhasilan atau target yang akan dicapai dalam proses pendidikan islam dan proses pembelajaran. Dengan demikian evaluasi bukan sekedar menilai suatu aktivitas secara spontan dan incidental, melainkan merupakan kegiatan untuk menilai sesuatu secara terencana, sistematik, dan berdasarkan atas tujuan yang jelas.

Sebagaimana dalam penelitian yang dilakukan oleh (Muslim A. , 2017), evaluasi merupkan salah satu kegiatan utama yang harus dilakukan oleh seorang tenaga pendidik dalam kegiatan pembelajaran. Dengan penilaian, guru akan mengetahui perkembangan hasil belajar, intelegensi, bakat khusus, minat, hubungan sosial, sikap dan kepribadian siswa atau peserta didik. Aktifitas dalam penilaian ini dilakukan dalam rangka untuk mengukur tingkat ketercapaian kompetensi peserta didik dalam kurrun waktu tertentu, selain itu juga dapat dijadikan sebagai bahan penyusunan laporan kemajuan hasil belajar, hingga dapat diketahui perbaikan-perbaikan yang barangkali perlu dilakukan.

Selain itu evaluasi juga bertujuan untuk menjamin kinerja yang dicapai agar sesuai rencana dan tujuan yang telah ditetapkan. Yang terpenting evaluasi pembelajaran harus dilakukan berkesinambungan (terus menerus) untuk mengetahui dan memantau perubabhan serta kemajuan yang dicapai peserta didik, maupun untuk memberi skor, angka atau nilai yang biasa dilakukan pada penilaian hasil belajar.

\section{Kesimpulan dan Implikasi}

Visi pengembangan madrasah merupakan upaya membawa lembaga tersebut ke masa depan, melalui analisis internal dan eksternal. Kemampuan merumuskan visi yang baik mesti menjadi salah satu kompetensi tim manajemen madrasah. Visi akan menjadi pemandu pengelolaan sekolah, yang berarti membumikan fungsifungsi dasar manajemen meliputi: perencanaan, pengorganisasian, pelaksanaan, pengendalian dan evaluasi. Sebagai implikasi, studi ini menyarankan perlunya penelitian lanjutan tentang strategi menciptakan keunggulan bersaing di MAN Insan Cendekia Kendari. Topik lain yang dapat dikembangkan adalah budaya organisasi di MAN Insan Cendekia. 


\section{Daftar Pustaka}

Akilah, F. (2017). Manajemen Perencanaan Sumber Dayya Manusia di Bidang Pendidikan: Manifestasi dan Implementasi. Journal Kependidikan, Vol. 11 No. 1, Juni, 81-94.

Almasari, M. N. (2016). Manajemen Sumber Daya Manusia: Implementasi Dalam Penndidikan Islam. Vol. 12, No. 2 JuliDesember , 134.

Amaliyah, T. (204). Penerapan Fungsi-Fungsi Manajemen Dalam Meningkatkan Kualitas Bimbingan Pada Kelompok Bimbingan Ibadah Haji (KBIH) Arotah Kaliwungu Kendal. DISS, UIN Walisongo .

Anggito, A., \& Setiawan, J. (2018). Metodologi penelitian kualitatif. CV Jejak (Jejak Publisher).

Baiturrahman, B. (2019). Analisis Kebijakan Kementerian Agama Tentang Pengembangan Madrasah (Kasus MAN Insan Cendekia) (Doctoral dissertation, Universitas Muhammadiyah Malang).

Creswell, J. W., \& Poth, C. N. (2016). Qualitative inquiry and research design: Choosing among five approaches. Sage publications.

Daryanto. (2013). Administrasi dan Manajemen Sekolah. Jakarta: Rineka Cipta.

Deliasari, A., \& Kurnianingsih, I. (2017). Analisis Kebutuhan Topik Pembelajaran Literasi Informasi Online Pada Perpustakaan Sekolah MAN Insan Cendekia. Edulib, 7(2).

Gunawan, I. (2014). Metode Penelitian Kualitatif Teori dan Praktek. Jakarta: Bumi Aksara.

Hartin, H. (2020). Human Resources Oriented: Kerangka Strategis Pengembangan MAN Insan Cendekia Kendari. Shautut Tarbiyah, 26(1), 50-68.

Hidayati, U. (2019). Inovasi Madrasah Melalui Penyelenggaraan Madrasah Riset. Edukasi, 17(3), 294679.

Husaini, U. (2013). Manajemen. Jakarta: Bumi Aksara.

Kasali, R. (2019). Disruption" Tak ada yang tak bisa diubah sebelum dihadapi motvasi saja tidak cukup".

Miles, M. B., \& Huberman, A. M. (1994). Qualitative data analysis: An expanded sourcebook. Sage. 
Mubarok, A. (2018). Strategi Peningkatan Pembelajaran Melalui Manajemen Boarding School. Jurnal Pendidikan Agama Islam, Vol. 3, No.2, Juni , 244.

Nanus, B., \& Dobbs, S. M. (1999). Leaders who make a difference: Essential strategies for meeting the nonprofit challenge.

Nurdin, A. (2016). Inovasi Pembelajaran Pendidikan Agama Islam di Era Information and Communication Technology. TADRIS: Jurnal Pendidikan Islam, 11(1), 49-64.

Robbins, S. P., \& Judge, T. (2012). Essentials of organizational behavior.

Sastramayani, S., \& Badarwan, B. (2019). Kepemimpinan Krisis dalam Pengelolaan Sekolah. Shautut Tarbiyah, 25(2), 181201.

Siregar, E. \&. (2011). Teori Belajar dan Pembelajaran. Bogor: Ggraha Inndonesia.

Solong, N. P., Munirah, M., \& Arif, M. (2020). Effective School Management At Man Insan Cendekia Gorontalo. Lentera Pendidikan: Jurnal Ilmu Tarbiyah dan Keguruan, 23(1), 2232.

Syahrul, S. (2015). Kepemimpinan dan Inovasi Lembaga Pendidikan (Pengalaman Pondok Gontor VII Putra Sulawesi Tenggara). Al-TA'DIB: Jurnal Kajian Ilmu Kependidikan, 8(1), 82-100.

Syahrul, S. (2015). Mengelola Perguruan Tinggi dalam Iklim Ketidakpastian (Memahami Dinamika Perencanaan Strategis di STAIN Sultan Qaimuddin Kendari). Al-Izzah: Jurnal Hasil-Hasil Penelitian, 10(1), 143-160.

Syahrul, S. (2016). Readines Frame: Analisis Kerangka Kesiapan dalam Transformasi Pendidikan Tinggi (Pengalaman Iain Kendari). Al-TA'DIB: Jurnal Kajian Ilmu Kependidikan, 9(1), 162-181.

Syahrul, S., Alim, N., Pairin, P., \& Nur, J. (2019). Utilization of management information systems in managerial supervision at IAIN Kendari. International Journal of Recent Technology and Engineering (TM), 8(1C2), 392-392.

Syahrul, S. (2019). Invisible Competition: Pergulatan Membangun Keunggulan dalam Bingkai Tradisi di Pesantren Annur Azzubaidi, Konawe, Sulawesi Tenggara.

Torang, S. (2014). Organisasi dan Manjemen. Bandung: Alfabeta. 
Apud, A. (2018). Manajemen mutu pendidikan man insan cendekia.

Tarbawi: Jurnal Keilmuan Manajemen Pendidikan, 4(02), 171-190.

Yacoeb. (2013). Konsep Manajemen Dalam Perspektif Al-Qur'an: Suatu Analisis Dalam Bidang Administrasi Pendidikan. Jurnal Ilmiah DIDAKTIKA, Vol. XIV, No. 01, Agustus .

Yaqin, N. (2015). Makna Manajemen Bagi Pembangunan Pesantren Nurul Yaqin. Jurnal Studi Islam, Vol. 2, No. 2, Juni , 124130.

Zaenal, R. M. (2018). Manajemen Boarding School Dalam Peningkatan Belajar Siswa. Jurnal SPs UNINUS. Vo. 1, No. 1 September, 80. 